\title{
Hydrogen bond nets in dithionate metal salt crystals
}

\author{
Robert A. Burrow* and Rafael Duarte
}

Chemistry Department, Federal University of Santa Maria, Santa Maria, RS, Brazil, 97105-070 *rburrow@ufsm.br

Seven dithionate aqua complexes of the transition metal ions $\mathrm{Mn}^{2+}, \mathrm{Fe}^{2+}, \mathrm{Co}^{2+}, \mathrm{Ni}^{2+}, \mathrm{Cu}^{2+}, \mathrm{Zn}^{2+}$ and $\mathrm{Cd}^{2+}$ were synthesized and their crystal structures determined, giving three coordination polymers - catena-poly-[trans-tetraaquamanganese- $\mu$-dithionato- $\left.{ }^{2} \mathrm{O}, \mathrm{O}^{\prime}\right],\left[\mathrm{Mn}\left(\mathrm{H}_{2} \mathrm{O}\right)_{4}\left(\mathrm{~S}_{2} \mathrm{O}_{6}\right)\right]$ 1, catena-poly-[trans-tetraaquacopper- $\mu$-dithionato- $\left.{ }^{2} \mathrm{O}, \mathrm{O}^{\prime}\right], \quad\left[\mathrm{Cu}\left(\mathrm{H}_{2} \mathrm{O}\right)_{4}\left(\mathrm{~S}_{2} \mathrm{O}_{6}\right)\right], \quad 5$ and catena-poly[trans-tetraaquacadmium- $\mu$-dithionato- $\left.{ }^{2} \mathrm{O}, \mathrm{O}^{\prime}\right],\left[\mathrm{Cd}\left(\mathrm{H}_{2} \mathrm{O}\right)_{4}\left(\mathrm{~S}_{2} \mathrm{O}_{6}\right)\right] 7$ - and four complex salts hexaaquairon(2+) dithionate hydrate, $\left[\mathrm{Fe}\left(\mathrm{H}_{2} \mathrm{O}\right)_{6}\right]\left(\mathrm{S}_{2} \mathrm{O}_{6}\right) \cdot \mathrm{H}_{2} \mathrm{O} 2$, hexaaquacobalt $(2+)$ dithionate, $\left[\mathrm{Co}\left(\mathrm{H}_{2} \mathrm{O}\right)_{6}\right]\left(\mathrm{S}_{2} \mathrm{O}_{6}\right) 3$, hexaaquanickel $(2+)$ dithionate, $\left[\mathrm{Ni}\left(\mathrm{H}_{2} \mathrm{O}\right)_{6}\right]\left(\mathrm{S}_{2} \mathrm{O}_{6}\right) 4$ and hexaaquazinc $(2+)$ dithionate, $\left[\mathrm{Zn}\left(\mathrm{H}_{2} \mathrm{O}_{6}\right]\left(\mathrm{S}_{2} \mathrm{O}_{6}\right) 6\right.$, Figure 1. All crystallized in the triclinic space group $P \overline{1}$. Hirshfeld surface fingerprint plots $^{1-3}$ were used to map the interactions within the crystal structures. The structures were analyzed by Quantum Theory of Atoms in Molecules ${ }^{4,5}$ to determine the bond critical points and to estimate the energy of the hydrogen bonds. The structural differences were rationalized using Pauling packing rules. ${ }^{6}$

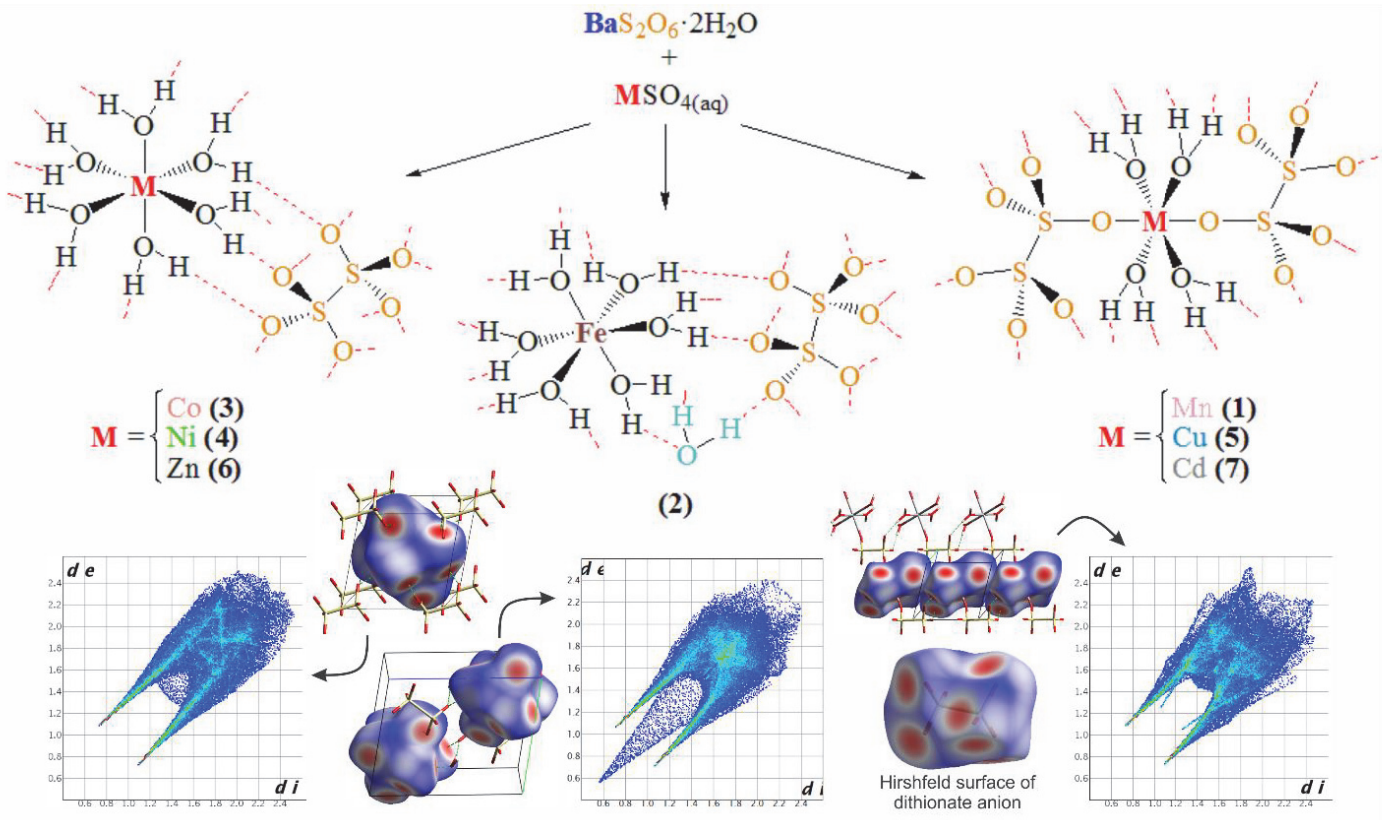

Figure 1. Synthetic scheme, Hirshfeld surfaces and fingerprint plots of complex salts and coordination polymers with the anion dithionate.

\section{References}

1 M. A. Spackman and J. J. Mckinnon, Cryst. Eng. Comm., 2002, 4, 378-392.

2 J. J. Mckinnon, D. Jayatilaka and M. A. Spackman, Chem. Comm., 2007, 3814-3816.

3 E. Espinosa, E. Molins and C. Lecomte, Chem. Phys. Lett., 1998, 285, 170-173.

4 R. F. W. Bader, Atoms in Molecules: A Quantum Theory, Oxford University Press: Inc., Oxford, UK, 1990.

5 M. A. Spackman, Cryst. Growth Des., 2015, 15, 5624-5628.

6 L. Pauling, J. Am. Chem. Soc., 1929, 51, 1010-1026. 